FIU Law Review

\title{
70 Years of the International Law Commission, Its Future Role in the Changing Landscape of International Law and the Small- Developing States Nexus
}

\author{
Michael Imran Kanu \\ Dr. Michael Imran Kanu is Ambassador/Deputy Permanent Representative for Legal Affairs, \\ thePermanent Mission of the Republic of Sierra Leone to the United Nations in New York, \\ sierraleoneun.dprlegal@gmail.com
}

Follow this and additional works at: https://ecollections.law.fiu.edu/lawreview

Part of the International Law Commons, and the State and Local Government Law Commons

Online ISSN: 2643-7759

\section{Recommended Citation}

Michael I. Kanu, 70 Years of the International Law Commission, Its Future Role in the Changing Landscape of International Law and the Small-Developing States Nexus, 13 FIU L. Rev. 1043 (2019). DOI: https://dx.doi.org/10.25148/lawrev.13.6.8

This Article is brought to you for free and open access by eCollections. It has been accepted for inclusion in FIU Law Review by an authorized editor of eCollections. For more information, please contact lisdavis@fiu.edu. 


\title{
70 YEARS OF THE INTERNATIONAL LAW COMMISSION, ITS FUTURE ROLE IN THE CHANGING LANDSCAPE OF INTERNATIONAL LAW AND THE SMALL-DEVELOPING STATES NEXUS
}

\author{
Michael Imran Kanu*
}

\begin{abstract}
The International Law Commission (ILC) in its 70 illustrious years has been credited with its acclaimed pivotal role in the progressive development of international law and its codification. However, given that the principle of consensus underpins the progressive development of international law and its codification, how much of this process has involved and incorporated the perspectives and needs of Small and Developing States? In the immediate aftermath of commemorating the 70th Anniversary of the ILC, this paper measures the level of participation by Small and Developing Sates and examines the future role of the ILC through the lens of its relationship with the Sixth Committee of the United Nations General Assembly. It asserts that the envisioned symbiosis and optimal actualization of the extensive engagement principle in the progressively development of international law and its codification is being inhibited by the current working relationship between the ILC and the Sixth Committee, coupled with the lack of resources and capacity on the part of Small and Developing States.

I. Introduction 1044

II. The ILC Programme of Work, Its Working Method and Sixth Committee Synergy ... 1047

III. The Work of the ILC - Measuring the Participation of Small and Developing States

A. The Sixth Committee Debates: How the Numbers Influence Substance. 1051

B. Written Comments and Observations by Member States on the Work of the ILC 1054

IV. The Future of the ILC in the Changing Landscape of International Law and Outlook from Small and Developing States 1055

\footnotetext{
* Dr. Michael Imran Kanu is Ambassador/Deputy Permanent Representative for Legal Affairs, the Permanent Mission of the Republic of Sierra Leone to the United Nations in New York. Email: deplamb.un@foreignaffairs.gov.sl.
} 
A. Sea level Rise in Relation to International Law: Attending to the Concerns of Small and Developing States 1055

B. Universal Criminal Jurisdiction: Sixth Committee Apparent Impasse and ILC's Usurpation?

V. Conclusion

Annex 1061

\section{INTRODUCTION}

The International Law Commission (Commission or ILC) is an independent, specialized body created by the General Assembly of the United Nations (UN) in 1947 and has the responsibility to assist the General Assembly in the discharge of its mandate under the Charter of the UN, which is to initiate studies and make recommendations in order to encourage the progressive development of international law and its codification. ${ }^{1}$ The mandate of the Commission was further defined by its Statute, shifting from "encouraging" to the "promotion of the progressive development of international law and its codification." 2 For convenience, "progressive development" is distinguished to mean work on subjects not yet regulated by international law or where the law is not sufficiently developed in the practice of States; whilst "codification" means the exact formulation and systematization of rules in areas where State practice, precedent and doctrine are extensive. ${ }^{3}$ This mandate, as elucidated, presupposes extensive, i.e., "allembracing," coverage of law texts, State practices, precedent, and doctrine in the development of international law, the restatement of existing rules, and in the reformulation of new ones. ${ }^{4}$

The Statute of the ILC imposes on the Commission the obligation to solicit the comments, observation, "the texts of laws, decrees, judicial decisions, treaties, diplomatic correspondence and other documents relevant to the topic being studied" from all Members of the UN. ${ }^{5}$ Soliciting the comments from Member States is fundamental and existential since the use of the final outcome of the work of the Commission is dependent on whether the expectations of Members States are reflected. In essence, the expectations

\footnotetext{
1 U.N. Charter art. 13, 11.

2 G.A. Res. 174 (II) (Nov. 21, 1947), as amended by G.A. Res. 485 (V) (Dec. 12, 1950), G.A. Res. 984 (X) (Dec. 3, 1955), G.A. Res. 985 (X) (Dec. 3, 1955), G.A. Res. $36 / 39$ (Nov. 18, 1981), Statute of the International Law Commission, art. 1(1).

3 Id. art. 15 .

4 See id. arts. 17(2)(b), 19(2), 21(2); U.N., THE WORK OF THE INTERNATIONAL LAW COMMISSION 1 (United Nations, 8th ed. 2007).

5 G.A. Res. 174, supra note 2, arts. 17(2)(b), 19(2), 21(2).
} 
of States should guide the work of the ILC. ${ }^{6}$ And in this context, the objective of this paper is to assess the degree of the extensive coverage of Member States comments and observations, law texts, State practice, precedent, and doctrine, with focus on Small Developing States (SDS). ${ }^{7}$ The paper asserts that the envisioned symbiosis and optimal actualization of the extensive engagement principle, when studies are initiated, in the progressive development of international law and its codification is being inhibited by the current working relationship between the ILC and the Sixth Committee, coupled with the lack of resources and capacity on the part of Small and Developing States. This then seems to lead to the conclusion that the Commission, in the main, is prone to pursue a limiting doctrinal vision with equally limited reference to the evolutionary and pluralistic nature of the international community. ${ }^{8}$

This paper in putting forward its claim, i.e., the insufficiency of representation and perspectives of all Member States in the work/output of the ILC relies on a significant claim, i.e., the claim that the international law landscape is changing, shifting from the traditional Westphalian legal order to a more pluralistic system. ${ }^{9}$ Whilst States' centrism is still prevalent at the $\mathrm{UN}$, with "sovereign equality" being at the heart of the UN Charter, ${ }^{10}$ it must be said that the landscape of international law has changed. This paper does not set out to address the issue of the changing landscape of international law, since it accepts the view that indeed the international law landscape has

6 See how this was captured in the deliberations of the Sixth Committee of the General Assembly in the Main Part of the 73rd Session. Press Release, Int'l Law Comm'n, International Law Commission Chair Highlights "Landmark Year," While Sixth Committee Delegates Urge Inclusion of New Topics, Statement by François Alabrune, U.N. Press Release GA/L/3579 (Oct. 22, 2018).

7 It is reported that half the world's sovereign states are small economies, with the majority being developing countries found in sub-Saharan Africa and the Caribbean Basin. Small and developing countries are characterized, in the economic sense, by small populations and markets, narrow and often undiversified resource base, fragility (political and economic) and prone to disruption by natural disasters and shocks. This paper does take a scientific view on definition, but it follows the characteristic elements described above. See Walter Kennes, Small Developing Countries and Global Markets: COMPETING IN THE Big League (2000); Tom Crowards, Defining the Category of "Small" States, 14 J. INT'L DEV. 143 (2002).

8 For a UN Member State view on this issue, see International Law Commission Chair Highlights "Landmark Year," supra note 6.

9 On this issue, see ThOmas L. Friedman, The World Is Flat: The Globalized World in THE TwENTY-FIRST CENTURY (2006); Daniel Bethlehem, The End of Geography: The Changing Nature of the International System and the Challenge to International Law, 25 EUR. J. INT'L L. 9 (2014); JOSÉ E. Alvarez, INTERNATIONAL ORgANIZATIONS AS LAW-MAKERS (2005); Anel Ferreira-Snyman, Sovereignty and The Changing Nature of Public International Law: Towards a World Law?, 40 COMP. \& InT'L L.J. S. AFR. 395 (2007); Catherine Turner, Delivering Lasting Peace, Democracy and Human Rights in Times of Transition: The Role of International Law, 2 InT'L J. TRANSNAT'L JUST. 136 (2008).

10 U.N. Charter art. 2, $₫ 1$. 
changed since the establishment of the ILC in $1947 .{ }^{11}$ In 1945 , when the UN Charter was being negotiated, the underlying ask was to "revitalize" and strengthen international law. ${ }^{12}$ Today, the focus seems to have shifted to addressing pluralism in international law and transboundary (beyondgeography) issues, including the environment, ocean affairs, security threats with respect to non-state actors and cyberspace, trade with emphasis to changes in the economic landscape, and threats to multilateralism. ${ }^{13}$ The threat to multilateralism, however, seems to suggest the need for the continued strengthening of international law. All this, however, adds to the fundamental shift that came with decolonization and state succession, and the attendant diversity in political systems and legal doctrines. It is worth noting that the Statute of the ILC envisaged geo-political landscape changes, and hence, in considering its membership, it is important to note that Member States are enjoined to ensure that "the main forms of civilization and ... the principal legal systems of the world" are represented at all times. ${ }^{14}$

This paper restricts its scope to the level of participation by Small and Developing States on the basis of their perceived low level of participation in the work of the ILC. A simple quantitative approach has been adopted to measure the level of engagements by Small and Developing States with the ILC. However, a qualitative analytical approach is adopted in examining the ILC's future role, with focus on the topics of "Sea-level rise in relation to international law" and "Universal criminal jurisdiction." In addition to this Introduction and the Conclusion, this paper is divided into three main sections. The next (second) section examines the ILC programme and working method in order to outline the path for synergy with the Sixth Committee, whilst the third section measures the level of participation by Small and Developing States in the work of the ILC within the past decade

11 The 70 years of the International Law Commission was commemorated under the theme "Drawing a balance for the future," with events organized in New York on 21 May 2018 and Geneva on 5 and 6 July 2018. In Geneva, a part of the commemorative events, a panel discussed "The changing landscape of international law." See Int'l Law Comm'n, Rep. on the Work of Its Seventieth Session, U.N. Doc. A/73/10 (2018).

12 "At the Conference held at San Francisco, April 25 to June 25, 1945, at which the Charter of the United Nations was drawn up, the measures that should be taken for 'revitalizing and strengthening' international law, shaken in the course of a quarter of a century by the upheaval of two World Wars, were considered by Committee II/2 of the Conference." Yeun-Li Liang, The General Assembly and the Progressive Development and Codification of International Law, 42 AM. J. INT'L L. 66, 66 (1948).

13 Bethlehem, supra note 9, at 9.

14 See G.A. Res. 174, supra note 2, art. 15. Note that the phrase is used in article 8 on the elections of ILC Members which certainly naturally takes into consideration the changing geo-political landscape in international affairs. Article 8 of the ILC States:

At the election the electors shall bear in mind that the persons to be elected to the Commission should individually possess the qualifications required and that in the Commission as a whole representation of the main forms of civilization and of the principal legal systems of the world should be assured. 
(2010-2019). The fourth section looks at the future role of the ILC, on the basis of two topics added to its long-term programme of work.

\section{THE ILC PROGRAMME OF WORK, ITS WORKING METHOD AND SIXTH COMMITTEE SYNERGY}

When the UN Charter was negotiated, especially paragraph 1 of article 13, the overwhelming view was that States were reluctant to grant the UN legislative power to adopt international rules that were binding, or to impose certain general conventions on States by majority vote. ${ }^{15}$ It is suggested, therefore, that Member States of the UN reserved unto themselves the determinant view on the systemization and formulation of the rules of international law and this is embodied in the Statute of the ILC. ${ }^{16}$ The ILC certainly relies on the Member States of the UN, especially in the Sixth Committee of the General Assembly, to effectively discharge its mandate. In fact, Member States' cooperation is one key denominator in determining the success of the ILC's output, since its work is dependent on the quality of the relationship between the Commission and Member States (mainly through their representatives in the Sixth Committee). ${ }^{17}$ The converse, which is also true, is that the General Assembly can only best utilize the ILC, in its advisory role under Article 13, paragraph 1 of the UN Charter, ${ }^{18}$ by enhanced cooperation between the two bodies.

In the Sixth Committee deliberations on the 2018 Report of the ILC, Member States expressed challenges, and perhaps dissatisfaction, over the inability of States to interact with the Commission by way of substantial comments, observations in writing and in the usual autumn deliberations in New York. ${ }^{19}$ Challenges include States' limited financial and human resources to engage the ILC reports, high number of topics being dealt with by the Commission, and the choice of topics by the Commission. For example, the African Group in the 2018 debate, expressed optimism for

15 See U.N. Conference on International Organization, Documents of the United Nations Conference on International Organization, San Francisco, 1945, U.N. Doc. 1, 2 (Vol. III); U.N. Doc. 1151 (Vol. VIII); U.N. Doc. 203, 416, 507, 536, 571, 792, 795, 848 (Vol. IX). See also U.N. Int' L. Commission, Drafting and Implementation of Article 13, paragraph 1, of the Charter of the United Nations, http://legal.un.org/ilc/drafting.shtml (last updated July 31, 2017).

16 G.A. Res. 174, supra note 2, arts. 16, 19, 21, 22.

17 See Mr. François Alabrune Director of Legal Affairs, Ministry of Europe and Foreign Affairs, France on the Report of the International Law Commission on the Work of Its Seventieth Session, at the 73rd Session of the United Nations General Assembly Sixth Committee (Oct. 22, 2018).

18 U.N. GAOR, 2nd Sess., 6th Comm., Annex 1g. See also Drafting and Implementation of Article 13, paragraph 1, of the Charter of the United Nations, supra note 15.

19 Statements of the African Group, Mauritius in the Individual capacity, France and Belgium (in the informal dialogue during the 73rd Session of the General Assembly) echo this sentiment. 
improvement in the presentation of the ILC report but also called for a userfriendly way to present it for better understanding and appreciation by all delegations. ${ }^{20}$ The delegation of Mauritius specifically had this to say:

The ILC relies on the feedback of Member States to progress its work. It is indeed obliged to do so by virtue of provisions within Articles 16, 19, 21 and 22 of the Statute of the ILC itself. This requires the ILC to circulate questionnaires to Governments, request from the latter texts of laws, decrees, judicial decisions and other documents relevant to the topics being studied, as well as to invite comments on drafts of its work. For the ILC, receiving comments and information from Member States is fundamental to its work. However, it is important to take into consideration issues of capacity, whereby some Member States, including African States and Small Island Developing States (SIDS) can be at a disadvantage when it comes to timely compilation of documents and adequate follow-up on the ILC requests.

In this context, it is proposed that due consideration be given, in the near future, for the ILC/Secretariat to provide a clear, concise summary of the yearly report to facilitate the study of the topics in the report and to provide sufficient "food for thought" to delegations in view of the International Law Week within the Sixth Committee. At present, the bulky report is released each year around mid-September, i.e., when Member States are already busy preparing for the High-Level week of the General Assembly. Insufficient time to prepare and the arcane language in the reports, with lengthy procedural details about proceedings and commentaries on draft proposals, make for some very difficult reading and eventually it is difficult to grasp the substantive marrow of the topics in the report. ${ }^{21}$

Notwithstanding the expression of the series of challenges by some Member States, the Sixth Committee proceeded to adopt a consensus resolution taking note of the report of the Commission. ${ }^{22}$ Does this lend credence to argument that the regular and readily adoption of the report of the ILC, by the Sixth Committee, is the best proof of the relationship between

20 Statement from the African Group by Mr. Amadou Jaiteh, First Secretary of the Permanent Mission of The Gambia before the Sixth Committee, 73rd session of the United Nations General Assembly under Agenda Item 82 "Report of the International Law Commission on the Work of Its Seventieth Session” (Oct. 22, 2018).

21 Statement from the Distinguished Representative of Mauritius on the 6th Committee of the General Assembly during Law Week (Oct. 22-31, 2018) on the Report of the International Law Commission on the Work of https:/gadebate.un.org/sites/default/files/gastatements/71/71_MU_en.pdf.

22 G.A. Res. 73/265 (Jan. 14, 2019). 
the ILC and the General Assembly? This seems to have been one of the suggestions coming from the 70th Anniversary solemn commemorative session in New York. ${ }^{23}$ Regardless of the position to be taken on this issue, it is important to note that the working method of the ILC enhances cooperation, since the breath of the work of the ILC involves or anticipates the intervention/participation of States. However, the limited participation of Member States in considering the work of the ILC begs the question: is the ILC de facto international law-maker? The answer could be found in the working methods of the ILC and the role of States.

The Commission's current working methods are not readily apparent from the Statute, which needs to be read in light of the practice of the Commission and General Assembly as it has evolved since 1947. While the Statute does establish the basic framework for the organization of the Commission, its working methods, and indicates the outcomes of its work, it has not acted as a straitjacket. But it nevertheless remains the starting point for an understanding of the Commission. ${ }^{24}$

Based on the ILC Statute, the working methods of the ILC is said to allow for the participation of States at various stages, from the possibility to propose a certain topic; ${ }^{25}$ responses to requests for data and information from Governments in the preliminary stage of the study of a topic; to commenting on initial and final drafts; in between the first and second readings; through written comment and observations from Governments; or through the Sixth Committee; and culminating in the General Assembly giving consideration to the final work of the ILC on a given topic. ${ }^{26}$ Further, the "Commission's

23 The Records of the ILC New York Solemn Session, Statement by the [ILC Chair].

24 Sir Michael Wood, Statute of the International Law Commission, UNITED NATIONS (2009), www.un.org/law/avl.

25 G.A. Res. 174, supra note 2, arts. 16-18. See THE WORK OF THE INTERNATIONAL LAW COMMISsion, supra note 4, at 33-34. The criteria for the selection of topics demonstrates this States-led focus:

(i) the topic should reflect the needs of States in respect of the progressive development and codification of international law; (ii) the topic should be at a sufficiently advanced stage in terms of State practice to permit progressive development and codification; (iii) the topic should be concrete and feasible for progressive development and codification; and (iv) the Commission should not restrict itself to traditional topics, but should also consider those that reflect new developments in international law and pressing concerns of the international community as a whole.

Programme of Work-About the Commission, INT'L LAW COMM'N, http://legal.un.org/ilc/programme.shtml (last visited May 15, 2019).

26 The Commission has identified three different stages generally present in the consideration of a topic on its agenda: a preliminary stage, devoted mainly to the organization of work and the gathering of relevant materials and precedents; a second stage, during which the Commission proceeds to a first reading of the draft articles submitted by the Special Rapporteur; and a third and final stage, devoted to a second reading of the draft provisions provisionally adopted. 
decision to commence its work on a topic is mainly influenced by the status of the consideration of other topics and requests by the General Assembly," including requests to give priority to certain topics. ${ }^{27}$ Therefore, the path for cooperation between the legal and technical ILC, with its members acting independently, and the politically influenced Sixth Committee is evident in the working method of the ILC. ${ }^{28}$

Since the Sixth Committee is the platform for the political and legal synergy that is needed to achieve the goals of article 13 paragraph 1 of the UN Charter, it must be said that the path is laid out for the active participation of all States, including Small and Developing States. This seems to have been the case for the newly independent States, in the wake of decolonization, on the important topics of the law of treaties and State succession. In his keynote address at the Geneva solemn commemoration of the 70th anniversary of the ILC, Justice Mr. Abdulqawi Ahmed Yusuf, President of the International Court of Justice, submitted that delegates of the newly independent States in the Sixth Committee influenced the provision of invalidity of a treaty procured by threat or the use of force in the law of treaties, and also ignited interest in the consideration of the provisional application of treaties. ${ }^{29}$ This goes to show that when States are in a position to engage in the work of the ILC, the programme and method of work provide the path to do so. Therefore, what must be of interest to Small and Developing States is the mobilization of resources and the streamlining of the ILC work programme to further enhance their level of engagement.

Methods of Work-About the Commission, INT'L LAW COMM'N, http://legal.un.org/ilc/methods.shtml (last visited May 15, 2019). See U.N., YEARBOOK OF THE INTERNATIONAL LAW COMMISSION, U.N. Doc. A/CN.4/325, U.N. Sales No. E.80V.5 (Part II) (1991); Rep. of the Working Group on Review of the Multilateral Treaty-Making Process, $\uparrow$ 35, U.N. Doc. A/CN.4/325 (July 23, 1979).

27 The Commission has usually recommended that the General Assembly take action envisaged with respect to the codification of international law under its statute, namely: (a) to take no action, the report having already been published; (b) to take note of or adopt the report by resolution; (c) to recommend the draft to Members with a view to the conclusion of a convention; or (d) to convoke a conference to conclude a convention (article 23, paragraph 1).

United Nations, Methods of Work-About the Commission, INT'L LAW COMM'N, http://legal.un.org/ilc/methods.shtml (last updated Jan. 11, 2019).

28 In the drafting of article 13 paragraph 1 whilst some members of the Committee stressed the scientific and non-political nature of the work to be performed by the proposed commission, the majority of the Committee took the view that the work of the commission should always be carried out in close cooperation with the political authorities of States and that actions in respect of the drafts prepared by the Commission should be decided upon by the General Assembly.

United Nations, International Law Commission: Drafting and Implementation of Article 13, Paragraph 1, of the Charter of the United Nations, INT'L LAW COMM'N, http://legal.un.org/ilc/drafting.shtml (last updated July 31, 2017).

29 Int'l Law Comm'n, Rep. on the Work of Its Seventieth Session, U.N. Doc. A/73/10, at 295 (2018). See Vienna Convention on the Law of Treaties art. 52, May 23, 1969, U.N.T.S. 1155 http://legal.un.org/ilc/texts/instruments/english/conventions/1_1_1969.pdf. 


\section{THE WORK OF THE ILC-MEASURING THE PARTICIPATION OF SMALL AND DEVELOPING STATES}

In the margins of the ILC 70th anniversary commemoration, a panel discussion was held on the topic: "Enhancing the Contribution of Small and Developing States to the Work of the ILC." ${ }^{30}$ The framing of the topic is telling in terms of the level of contribution of Small and Developing States, at least, in the last decade. Certainly, the literature on the achievements of the ILC is vast, and acres of papers and streams of ink need not be consumed in rehearsing the story. Perhaps what is missing is the measure of the level of participation by Small and Developing States. This section examines the issue by quantitatively assessing the level of contribution/engagement on the reports of the ILC in the Sixth Committee and by written comments or observations on the work of the ILC by Member States as invited by the Commission. ${ }^{31}$

\section{A. The Sixth Committee Debates: How the Numbers Influence Substance}

With the General Assembly being the main deliberative organ of the United Nations ("UN") and having all 193 Members of the UN represented, it presents a significant platform to measure the level of engagement of Small and Developing States with respect to the work of the ILC. The approach which has been taken in this section of the paper is to quantify the number of Small and Developing States commenting overtime in the last decade, since the ILC invariably would have considered the substance of their comments as the ILC 2018 indicates. For example, with respect to the addition of the topic "sea-level rise in relation to international law," the annex syllabus made it clear that the number of countries (15) which called for the inclusion of the topic in the Commission's Long-Term Programme of Work, and the number of other Member States (9) which expressed the importance of the topic impacted on its consideration. ${ }^{32}$ In some sense, what this is saying is simply that the consideration of the substance is in part linked to the number of countries that consider a topic relevant for the ILC to study, although the Commission acts independently.

30 Side-event—Panel discussion on "Enhancing the Contribution of Small and Developing States to the Work of the ILC," was organized by Honduras, Saint Lucia, Fiji and Ghana on 17 May 2018. See ILC, 70th Session (2018): 70th Anniversary of the ILC, (last visited Feb. 18, 2019), http://legal.un.org/ilc/sessions/70/70thanniversary/events.shtml.

31 See G.A. Res. 174, supra note 2, arts. 16-18.

32 Int'l Law Comm'n, Rep. on the Work of Its Seventieth Session, supra note 29, at 326-27. 
The level of engagement by Small and Developing States can be quantified by reference to national or group statements delivered in the Sixth Committee debates on the ILC reports. In this paper, this quantitative look has been limited to the last decade, from 2010 to 2019. In the Sixth Committee's consideration of the 62 nd session report of the ILC in $2010,{ }^{33}$ which debated items in the current programme of work of the Commission as reflected in the report then, the number of States that contributed to the debate is estimated at 55, and three of which were group statements for the Nordic countries, Rio Group and European Union respectively. ${ }^{34}$ The number of countries that fit the characterization of Small and Developing Countries is estimated to be less than ten. There was about the same level of engagement in the Sixth Committee when it considered ILC's 63rd session report in $2011 .^{35}$ The total number of States that contributed to the debate is estimated 60 , with similar three respective group statements, and about 12 Small and Developing States delivered national statements. ${ }^{36}$ There was, however, significant interest from international organizations since the topic "responsibility of international organizations" was part of the clustered items tabled for the plenary debate. ${ }^{37}$

In the Sixth Committee consideration of the report of the ILC in 2012, 58 Member States delivered national statements, three group statements on behalf of the Nordic countries, the Community of Latin American, and Caribbean States (CELAC) and the European Union respectively. ${ }^{38}$ The statements by Chile (on behalf CELAC), and a few more African States, including the Congo and Zambia, added to the traditional voices to augment the contribution of Small and Developing States. This encouraging sign of a group statement from CELAC continued in 2013, in the Sixth Committee's

33 G.A. Res. 65/26 (Jan. 10, 2011). The Sixth Committee considered the ILC's sixty-second session report at its 19th to 26th and 28th meetings, from 25 to 29 October, and on 1 and 11 November 2010. See Int'1 Law Comm'n, Rep. on the Work of Its Sixty-Second Session (Agenda item 79), U.N. Doc. A/65/10, http://www.un.org/en/ga/sixth/65/ILC.shtml (last visited March 6, 2019).

34 For a list of representatives' statements, see Int'l Law Comm'n, Rep. on the Work of Its SixtySecond Session (Agenda item 79).

35 G.A. Res. 65/28 (Jan. 10, 2011). The Sixth Committee considered the ILC's sixty-third session report at its 18 th to 28 th meetings and at its 30th meeting, from 24 to 28 October, on 31 October and on 1, 2, 4, and 11 November 2011. See Int'l Law Comm'n, Rep. on the Work of Its Sixty-Third Session (Agenda item 81).

36 Id.

37 Id.

38 G.A. Res. $67 / 92$ (Jan. 14, 2013). The Sixth Committee considered the ILC's sixty-third and sixty-fourth sessions report at its 18 th to 25 th meetings, on 1, 2, 5, 6, 7, 9, and 16 November 2012. See Int'l Law Comm'n, Rep. on the Work of Its Sixty-Third and Sixty-Fourth Sessions (Agenda item 79) (2012). 
consideration of the ILC report. ${ }^{39}$ About 51 Member States delivered national statements, with three group statements from CELAC, Nordic countries, and the European Union respectively. In sharp contrast, only South Africa delivered a statement from the African geographical region. ${ }^{40}$

The 2014 report of the ILC on its 66th session was debated in the Sixth Committee with increased group statements from CELAC, European Union, the Nordic countries and Tonga on behalf of the Pacific Small Island Developing States (PSID). ${ }^{41}$ About 57 States delivered national statements, with three from African States. ${ }^{42}$ In 2015, the Sixth Committee considered the report of the ILC on its work during its 67 th session. ${ }^{43}$ The number of group statements reverted to three from CELAC, European Union, and Nordic countries, with an estimated 60 national statements, including Algeria, the only country from Africa. ${ }^{44}$ In the 2016 Sixth Committee consideration of the 68th session report of the ILC, there were three group statements from CELAC, Nordic countries, and the European Union respectively, and about 63 national statements, three of which were from Egypt, South Africa, and Sudan in Africa. ${ }^{45}$ In 2017, the ILC report on its 69th session attracted even more group statements in the Sixth Committee, as the number increased to five, including CELAC, Nordic countries, European Union, PSID, and from the Caribbean Community (CARICOM) respectively. ${ }^{46}$ There were 61 Member States intervention in all, with the African participation increased to 6 countries.

The 70th anniversary of the ILC was commemorated in the Sixth Committee in $2018,{ }^{47}$ and the increase in the level of participation reflected

39 The Sixth Committee considered the ILC's sixty-third and sixty-fifth sessions report at its 17 th to 26th and 29th meetings, on 28, 29, 30, 31 October, and 1, 4, 5, and 15 November 2013. See Rep. of the Int'1 Law Comm'n on the Work of Its Sixty-Third and Sixty-Fifth Sessions, supra note 38.

40 Id.

41 The Sixth Committee considered the ILC's sixty-sixth session report at its 19th to 27th and 29th meetings, on 27, 28, 29, 31 October, and 3, 5, and 14 November 2014. See Int'l Law Comm'n, Rep. on the Work of Its Sixty-Sixth Session (Agenda item 81).

42 Id.

43 The Sixth Committee considered the ILC's sixty-seventh session report at its 17 th to 25 th and 29th meetings, on 2, 3, 4, 6, 9, 10, 11, and 20 November 2015. See Int'1 Law Comm'n, Rep. on the Work of Its Sixty-Seventh Session (Agenda item 83).

44 Id.

45 The Sixth Committee considered the ILC's sixty-eighth session report at its 20th to 30th and 33rd meetings, on 24 to 28 October, 1 to 3 and 11 November 2016. See Int'1 Law Comm'n, Rep. on the Work of Its Sixty-Eighth Session (Agenda item 78).

46 The Sixth Committee considered the ILC's sixty-ninth session report at its 18th to 26th and 30th meetings, from 23 to 27 and on 31 October and 1 and 10 November 2017. See Int'1 Law Comm'n, Rep. on the Work of Its Sixty-Ninth Session (Agenda item 81).

47 The Sixth Committee considered the ILC's seventieth session report at its 20th to 30th and 35th meetings, from 22 to 26 October, on 30 and 31 October and on 13 November 2018. See Int'1 Law Comm'n, Rep. on the Work of Its Seventieth Session (Agenda item 82). 
the significance of the 70th session of the Commission. There were six group statements from the African Group, CARICOM, CELAC, European Union, Nordic countries and the Pacific Island Form (PIF) respectively. ${ }^{48}$ The number of Member States interventions increased to 76. By all means, the level of participation in the 70th session of the ILC should reflect the level of engagement anticipated in 1947, when the Commission was established. However, there seem to be a constant quantum of Member States participating the Sixth Committee debates on the reports of the ILC, with the majority being developed countries from one geographical group. ${ }^{49}$ The pattern in the past decade suggests that Member States become engaged when a topic is of particular interest or when there is a buzz in the international community, for example, the 70th anniversary commemoration of the ILC. Significantly, it must be underscored that practice of group statements seems to be the route to reflect a broader range of views on the work of the ILC during the Sixth Committee debates. This practice may provide needed respite and pathway to increase the level of engagement by Small and Developing States.

\section{B. Written Comments and Observations by Member States on the Work of the ILC}

The Statute of the ILC, as previously argued above, imposes an obligation on the Commission to solicit the comments, observation from all Members of the UN on its work. ${ }^{50}$ This is meant to meet the extensive coverage mandate in the restatement of existing international norms and in the reformulation of new rules. In the past decade, counting upwards from 2010, there have been 8 requests to Member States for written comments and observations on the work of the ILC. In the table annex to this paper, the data on the submission by Member States on topics based on requests from the ILC have been extracted. Three columns have been used to show the topic for which submissions were made, the stage in the consideration of the topic and the list of States that made submissions. The table paints a not so pretty picture in terms of the level of participation by Small and Developing States. When the table is scrutinized, it becomes apparent that there is a serious deficiency in the level of engagement by Small and Developing Countries.

$48 \quad I d$.

49 The Western European and Others Group (WEOG).

50 See G.A. Res. 174, supra note 2, arts. 17(2)(b), 19(2), 21(2). 


\section{THE FUTURE OF THE ILC IN THE CHANGING LANDSCAPE OF INTERNATIONAL LAW AND OUTLOOK FROM SMALL AND DEVELOPING STATES}

The future role of the ILC will be largely dependent on the quality of its relationship with the Sixth Committee, and there are two topics recently added to the Commission's long-term programme of work that provide a good litmus test to gauge the trajectory of the relationship between the Commission and the Sixth Committee. The topics are "Universal criminal jurisdiction" and "Sea-level rise in relation to international law." ${ }^{11}$ The manner in which the topics were recommended for addition in the Commission's long-term programme of work and degree of interest by Member States provide justification for their consideration in this paper. The Commission noted that in the selection of these topics, it was guided by recommendations it adopted in its 50th Session in $1998,{ }^{52}$ the relevance of the topics to the Member States being an integral part of the consideration.

\section{A. Sea level Rise in Relation to International Law: Attending to the Concerns of Small and Developing States}

The topic "Sea level rise in relation to international law" was proposed by five members of the Commission and was added to the long-term Programme of Work on the basis of a significant concern by Small and Developing States, especially the Small Islands and Developing States, considered to be significant members of the international community ${ }^{53}$ The syllabus proposing the topic noted that:

[The] phenomenon [of sea level rise] is already having an increasing impact upon many essential aspects of life for coastal areas, for low-lying coastal States and small island States, and especially for their populations. Another quite large number of States is likely to be indirectly affected (for instance, by the displacement of people or the lack of access to resources). Sea-level rise has become a global phenomenon and thus creates global problems, impacting on the international community as a whole. ${ }^{54}$

51 Int'l Law Comm'n, Rep. on the Work of Its Seventieth Session, U.N. Doc. A/73/10 (2018)

52 Id. at 370.

53 Id. at 326. The members of the Commission who were authors of the syllabus for the topic are Mr. Bogdan Aurescu, Mr. Yacouba Cissé, Ms. Patrícia Galvão Teles, Ms. Nilüfer Oral, and Mr. Juan Jośe Ruda Santolaria.

54 Id. at 326. 
What is evident in the syllabus and from the comments by Member States in the Sixth Committee is the high relevance of the topic to a significant number of States in the international community. In the 72nd session of the General Assembly, there was reported high level of interest and calls by no less than 15 Member States for the inclusion of the topic in the ILC's Long-Term Programme of Work; whilst nine others in their various national statements noted the importance of the topic. ${ }^{55}$ Further, the ILC 2018 report referenced the proposal of the Government of the Federated States of Micronesia on the "Legal Implications of Sea-level Rise" for inclusion in the ILC's Long-Term Programme of Work, as part of the Commission's 2018 consideration for the proposal and addition of the topic. ${ }^{56}$

In the Sixth Committee debate on the issue in the 73rd session of the General Assembly, Member States of the UN reiterated their interest in the topic. The 14 Member States of the CARICOM expressed their agreement with the ILC in that "the issue of sea level rise should be addressed more comprehensively, and as a matter of priority, given that [the] issue will have important direct implications for more than one-third of the international community, and indirect implications for all Member States." ${ }^{57}$ CARICOM even went further, calling for the scope of the topic to be expanded. ${ }^{58}$ With ILC concluding two topics in its current Programme of Work during its 70th session, CARICOM called for the inclusion of the topic in its current Programme of Work. ${ }^{59}$ The importance of the topic and the call for the topic to be included in the Commission's current Programme of Work was reechoed by the Pacific Islands Forum State Members. ${ }^{60}$ What became all too clear in the Sixth Committee is the huge significance a number of States have placed on the topic. It goes to show the faith in the ILC and respect for its technical expertise and rigor to address an issue with varying political positions, but with possible significant impact on statehood and the protection of persons that may be affected by sea-level rise. No one will refute the argument that the work of the Commission on this issue will be a

$55 \quad$ Id. at $326-27$.

$56 \quad$ Id. at 327.

57 H.E. Sheila Carey, Permanent Rep. of the Commonwealth of the Bahamas to the U.N., Rep. of the International Law Commission on the Work of Its Seventieth Session, at 2 (Oct. 22, 2018).

58 Id. at 3 (CARICOM "encourages the Commission to avoid narrowing the scope of topics in such a manner which might negatively impact the outcome's relevance and utility to Member States.").

59 Id.

60 H.E. Miss Amatlain E. Kabua, Republic of the Marshall Islands, on behalf of the Pacific Islands Forum members with Permanent Missions in New York, Statement from H.E. Miss Amatlain E. Kabua addressed to the members of the International Law Commission, on Agenda Item 82: Report of the International Law Commission on the Work of its Seventieth Session. Members of the Pacific Island States include Small and Developing States like Fiji, Kiribati, Federated States of Micronesia, Nauru, Palau, Papua New Guinea, Samoa, Solomon Islands, Tonga, Tuvalu, Vanuatu and Republic of the Marshall Islands. 
key determinant in measuring the level of interest in the ILC by States, especially those directly affected or to be impacted sea-level rise, the majority being Small and Developing States.

\section{B. Universal Criminal Jurisdiction: Sixth Committee Apparent Impasse and ILC's Usurpation?}

The topic, "Universal criminal jurisdiction," was recommended for inclusion in the ILC's long-term programme of work on the basis of a syllabus written by a member of the Commission. ${ }^{61}$ The inclusion of the topic follows from the ongoing decade-long debate in the Sixth Committee on a similarly framed topic, "The scope and application of the principle of universal jurisdiction. ${ }^{62}$ In the Sixth Committee debate on the agenda item, ${ }^{63}$ CELAC and CARICOM welcomed the addition of the topic in the Commission's Long-Term Programme of Work. ${ }^{64}$ Conversely, the African Group noted the inclusion of the topic in the long-term Programme of Work of the ILC but also resounded its resolve to retain the item in the Sixth Committee. The African Group commented on the state of play on the agenda item in the Sixth Committee as follows:

The concern of the African group lies in the abuse of the principle of universal Jurisdiction, which is a development that could endanger international law and the fight against impunity. The African Group is aware that some nonAfrican States and their domestic courts have sought to justify their arbitrary or unilateral application or

61 Int'1 Law Comm'n, supra note 51, at 307. Mr. Charles Chernor Jalloh authored the syllabus on the topic, and note that a member of the Commission can prepare a syllabus and propose that the be added to the long-term programme of work of the Commission through consensus by the working group on the long-term programme of work and the Commission at a plenary.

62 The topic, "The scope and application of the principle of universal jurisdiction," was included as an agenda item in the programme of work of the General Assembly pursuant to Assembly resolution 64/117 of 16 December 2009, following a Letter dated 21 January 2009 from the Permanent Representative of the United Republic of Tanzania to the United Nations addressed to the SecretaryGeneral requesting for the inclusion of an additional item in the agenda of the sixty-third session "Abuse of the principle of universal jurisdiction," and subsequently revised as framed in A/63/237/Rev.1.

63 U.N. GAOR, Report of the Sixth Committee: The Scope and Application of the Principle of Universal Jurisdiction, at 1, U.N. Doc. A/73/550 (2018).

64 See Permanent Rep. of El Salvador to the U.N., on behalf of the Community of Latin America and Caribbean States (CELAC), Statement dated October 9, 2018 from the Permanent Rep. of El Salvador to the United Nations addressed to the President of the General Assembly, on Agenda item 87: The Scope and Application of the Principle of Universal Jurisdiction; H.E. Sheila Carey, Permanent Rep. of the Commonwealth of the Bahamas to the U.N., on behalf of the Caribbean Community (CARICOM), Statement dated October 22, 2018 from Permanent Rep. of the Commonwealth of the Bahamas to the United Nations addressed to the Chairman of the International Law Commission, on Agenda Item 82: Report of the International Law Commission on the Work of its Seventieth Session. 
interpretation of the principle of universal Jurisdiction on customary international law.

We wish to remind those States that it is trite law recognized in all principal legal systems, and reflected in the Jurisprudence and decisions of the International Court of Justice, that a State which relies on a purported international custom practiced by States must, generally speaking, demonstrate to the satisfaction of the Court that the alleged custom has become so established as to be legally-binding on the other party.

What African countries and other like-minded States around the world are demanding is to call on the international community to adopt measures to put an end to the abuse of and political manipulation of the principle of universal Jurisdiction by Judges and politicians, including by violating the principle of the immunity of heads of state under international law. ${ }^{65}$

The African Group's major concern is the abuse of the principle of universal jurisdiction, which is perceived to be targeting unfairly and unilaterally African States. Although one may argue that African Group's composition is based on geographical location and therefore not exclusively within the Small and Developing States characterization box, it is noted that the membership of the African Group is the majority of Small and Developing States in the world. Thus, the position of the African group reflects the position of a sizeable fraction of the Small and Developing States.

The African Union Assembly of Heads of State and Government in January 2018 noted and described the inertia at the Sixth Committee on the topic as an "apparent impasse." 66 The "apparent impasse" has prevented meaningful progress in clarifying the scope and application of the principle of universal jurisdiction, despite good faith efforts by many delegations. ${ }^{67}$

65 Statement by Amadou Jaiteh, First Secretary of the Permanent Mission of the Gambia to the Sixth Committee of the United Nations General Assembly on "Scope and Application of the Principle of Universal Jurisdiction," Agenda Item 87 during the Seventy-Third Session of the General Assembly in New York, 9 October 2018.

66 African Union Assembly of Heads of State and Government, Decision on the International Criminal Court at 2, 30th Ordinary Session of the Assembly, Doc. EX.CL/1068/XXXII (Jan. 28-29, 2018).

67 Statement by H.E. Mrs. Nimatulai Bah-Chang, Deputy Minister of Foreign Affairs and International Cooperation to the Sixth Committee of the United Nations General Assembly on "cope and Application of the Principle of Universal Jurisdiction," Agenda Item 87 during the Seventy-Third Session of the General Assembly in New York, 9 October 2018. 
The "apparent impasse" seems to suggest a political stalemate, which may be outside the realms of law, and which can only be reconciled by a dispassionate legal exercise, as opposed to a political consensus. Thus, can the rigor and independence of the ILC provide the panacea? In the General Assembly resolution of 18 December 2017 on the agenda item, the UN agreed and contemplated the independent consideration of the issue of universal jurisdiction in other forums of the United Nations, which may and does include the ILC. ${ }^{68}$

The resolve by the African Group to retain the topic in the Sixth Committee interestingly fits within the resolution by the General Assembly to have multiple forums to consider the topic. This in practical terms means the scope and application will be subject to the legal-cum-political consideration of the Sixth Committee, whilst the ILC applies its technical legal expertise and rigor to the more restricted "criminal" consideration of universal jurisdiction. The delegation of Sierra Leone in the Sixth Committee expressed the view that indeed it was ripe for the ILC to take up the issue given the hopes of its technical rigor to be applied to forestall political abuse or misuse of the topic. ${ }^{69}$ The existing "treasure trove" of resources on State practice, texts of law, judicial decisions on universal jurisdiction, and the ILC's practical consideration of the topic was viewed by the Sierra Leone delegation as a work output that will be of high relevance for State Members. ${ }^{70}$ Navigating this fine balance between politics (expediency) and law (technical rigor) will go a long way to define the relationship between the Sixth Committee and the ILC, and by extension the future role of the ILC in the progressive development of international law and its codification, especially for the African Group, with the majority of Small and Developing States.

\section{CONClusion}

When the UN Charter was negotiated, the nations of the world had in mind the need to see the progressive development of international law and its codification through the initiation of studies by the General Assembly. The original intention was not to grant the UN (including any of its subsidiary agencies) international law-making powers, but for the General Assembly to make recommendations which could be taken up by States. The ILC was

68 See G.A. Res. 72/120, 2 (Dec. 18, 2018).

69 Statement by H.E. Mrs. Nimatulai Bah-Chang, Deputy Minister of Foreign Affairs and International Cooperation to the Sixth Committee of the United Nations General Assembly on "Scope and Application of the Principle of Universal Jurisdiction," Agenda Item 87 during the Seventy-Third Session of the General Assembly in New York, 9 October 2018.

$70 \quad I d$. 
[Vol. 13:1043

created to assist the General Assembly on an advisory technical basis. The Statute of the ILC reflected the intention of Member States as contained in the UN Charter, emphasizing an "all-embracing" approach. This presupposes a symbiosis between the ILC and the General Assembly. In this inclusive international law-making system, this paper has examined the level of engagement by Small and Developing States in the last decade of the 70 years of the ILC.

The paper finds that the envisioned symbiosis and optimal actualization of the extensive coverage principle is being inhibited by the current working relationship between the ILC and the Sixth Committee. This is made worse by the lack of resources and capacity on the part of Small and Developing States to regularly comment on the work of the ILC. Although the utilization of regional groups has elevated, to an extent, the level of engagement by Small and Developing States, the state of affairs is certainly undesirable and requires optimization. In this way, the recommendation for Small and Developing States to pull resources in responding to requests for comments and observation on the work of the ILC can be adopted, as the Nordic Countries of Denmark, Norway and Sweden are presently doing. Group statements may be compromised statement, but at the barest minimum, they provide insights on the position of States, which is valuable for the ILC. In addition to group statements, further actions including the practical measures of limiting the topics for consideration per session, putting out user-friendly and less-acne language reports will increase the levels of participation for all Member States, but most particularly, Small and Developing States. 
ANNEX

\begin{tabular}{|c|c|c|}
\hline NO. & $\begin{array}{l}\text { TOPIC } \\
(I L C R E A D I N G)\end{array}$ & $\begin{array}{l}\text { COMMENTS AND OBSERVATIONS } \\
\text { RECEIVED FROM GOVERNMENTS }\end{array}$ \\
\hline \multicolumn{3}{|c|}{ 70th Session (2018) } \\
\hline 1. & $\begin{array}{l}\text { Subsequent agreements } \\
\text { and subsequent practice } \\
\text { in relation to the } \\
\text { interpretation of treaties } \\
\text { (69th Session, } 2016 \mathrm{ILC} \\
\text { 1st reading) }\end{array}$ & $\begin{array}{l}\text { Belarus, the Czech Republic, El Salvador, } \\
\text { Germany, Netherlands, Spain, Sweden (on } \\
\text { behalf of the Nordic countries), the United } \\
\text { Kingdom of Great Britain and Northern } \\
\text { Ireland, and the United States of America } \\
\text { (2018). Austria and the Netherlands (2015). }\end{array}$ \\
\hline 2. & $\begin{array}{l}\text { Identification of } \\
\text { customary international } \\
\text { law (69th Session, } 2016 \\
\text { ILC } 1 \text { st reading })^{72}\end{array}$ & $\begin{array}{l}\text { Austria, Belarus, China, the Czech } \\
\text { Republic, Denmark (on behalf of the } \\
\text { Nordic countries: Denmark, Finland, } \\
\text { Iceland, Norway, and Sweden), El } \\
\text { Salvador, Israel, the Netherlands, New } \\
\text { Zealand, the Republic of Korea, Singapore, } \\
\text { and the United States of America (2018). }\end{array}$ \\
\hline \multicolumn{3}{|c|}{ 68th Session (2016) } \\
\hline 3. & $\begin{array}{l}\text { Protection of persons in } \\
\text { the event of disasters } \\
\text { (66th Session, 2014 ILC } \\
\text { 1st reading) }{ }^{73}\end{array}$ & $\begin{array}{l}\text { Australia, Austria, Cuba, the Czech } \\
\text { Republic, Ecuador, Finland (also on behalf } \\
\text { of Denmark, Iceland, Norway and Sweden), } \\
\text { Germany, the Netherlands, Qatar, and } \\
\text { Switzerland (2015-2016). Mexico and the } \\
\text { United States of America (2016). } \\
\text { Also international organizations and } \\
\text { entities: Office for the Coordination of } \\
\text { Humanitarian Affairs; secretariat of the } \\
\text { International Strategy for Disaster } \\
\text { Reduction; World Food Programme (WFP); } \\
\text { Food and Agriculture Organization of the }\end{array}$ \\
\hline
\end{tabular}

71 Rep. of the G.A., Subsequent Agreements and Subsequent Practice in Relation to the Interpretation of Treaties, U.N. Doc. A/CN.4/712 (2018); Rep. of the G.A., Subsequent Agreements and Subsequent Practice in Relation to the Interpretation of Treaties, U.N. Doc. A/CN.4/712/Add.1 (2018).

72 Rep. of the G.A., Identification of Customary International Law, U.N. Doc. A/CN.4/716 (2018).

73 Rep. of the G.A., Protection of Persons in the Event of Disasters, U.N. Doc. A/CN.4/696 (2016). 


\begin{tabular}{|c|c|c|}
\hline & & $\begin{array}{l}\text { United Nations (FAO); World Bank; } \\
\text { International Organization for Migration } \\
\text { (IOM); Association of Caribbean States; } \\
\text { Council of Europe; European Union; } \\
\text { International Committee of the Red Cross } \\
\text { (ICRC); and International Federation of } \\
\text { Red Cross and Red Crescent Societies } \\
\text { (IFRC) (2015-2016). }\end{array}$ \\
\hline \multicolumn{3}{|c|}{ 66th Session (2014) } \\
\hline 4. & $\begin{array}{l}\text { Expulsion of aliens (64th } \\
\text { Session, } 2012 \text { ILC 1st } \\
\text { reading })^{74}\end{array}$ & $\begin{array}{l}\text { Australia, Austria, Belgium, Canada, Cuba, } \\
\text { the Czech Republic, El Salvador, Germany, } \\
\text { Morocco, the Netherlands, the Republic of } \\
\text { Korea, the United Kingdom of Great } \\
\text { Britain and Northern Ireland, and the } \\
\text { United States of America (2014). Russian } \\
\text { Federation, Denmark, and European Union } \\
\text { (2014). }\end{array}$ \\
\hline \multicolumn{3}{|c|}{ 63rd Session (2011) } \\
\hline 5 . & $\begin{array}{l}\text { Responsibility of } \\
\text { international } \\
\text { organizations (61st } \\
\text { Session, } 2009 \text { ILC } 1 \mathrm{st} \\
\text { reading })^{75}\end{array}$ & $\begin{array}{l}\text { Austria, Cuba, El Salvador, Germany, and } \\
\text { Portugal (2010). Czech Republic, the } \\
\text { Republic of Korea, Mexico, the } \\
\text { Netherlands, and Switzerland (2011). Chile } \\
\text { (2011). } \\
21 \text { entities Council of Europe; } \\
\text { Comprehensive Nuclear-Test-Ban Treaty } \\
\text { Organization (CTBTO); European } \\
\text { Commission; International Civil Aviation } \\
\text { Organization (ICAO); International Fund } \\
\text { for Agricultural Development (IFAD); } \\
\text { International Labour Organization (ILO); } \\
\text { International Monetary Fund (IMF); } \\
\text { International Maritime Organization }\end{array}$ \\
\hline
\end{tabular}

74 Rep. of the G.A., Expulsion of Aliens, U.N. Docs. A/CN.4/669 (2014); Rep. of the G.A., Expulsion of Aliens, A/CN.4/669/Add.1 (2014).

75 Rep. of the G.A., Responsibility of International Organizations, U.N. Doc. A/CN.4/636 (2011); Rep. of the G.A., Responsibility of International Organizations, U.N. Doc. A/CN.4/636/Add.1 (2011); Rep. of the G.A., Responsibility of International Organizations, U.N. Doc. A/CN.4/636/Add.2 (2011). 


\begin{tabular}{|c|c|c|}
\hline & & $\begin{array}{l}\text { (IMO); International Organization for } \\
\text { Migration (IOM); } \\
\text { International Telecommunication Union } \\
\text { (ITU); North Atlantic Treaty Organization } \\
\text { (NATO); } \\
\text { Organization for Economic Cooperation } \\
\text { and Development (OECD); Organization } \\
\text { for Security and Cooperation in Europe } \\
\text { (OSCE); United Nations Educational, } \\
\text { Scientific and Cultural Organization } \\
\text { (UNESCO); International Institute for the } \\
\text { Unification of Private Law (UNIDROIT); } \\
\text { United Nations World Tourism } \\
\text { Organization (UNWTO); World Health } \\
\text { Organization (WHO); World Intellectual } \\
\text { Property Organization (WIPO); World } \\
\text { Meteorological Organization (WMO); } \\
\text { World Bank; and World Trade } \\
\text { Organization (WTO) (2011). }{ }^{76} \text { United } \\
\text { Nations. }{ }^{77}\end{array}$ \\
\hline 6. & $\begin{array}{l}\text { Reservations to treaties } \\
\text { (62nd Session, } 2010 \text { ILC } \\
\text { final version of the Guide } \\
\text { to Practice) })^{78}\end{array}$ & $\begin{array}{l}\text { El Salvador, Portugal, Bangladesh, } \\
\text { Australia, Finland, Germany, Norway, } \\
\text { Switzerland, Austria, and the United States } \\
\text { of America (2011). Republic of Korea, } \\
\text { United Kingdom of Great Britain and } \\
\text { Northern Ireland, France, Malaysia, and } \\
\text { New Zealand. }\end{array}$ \\
\hline \multicolumn{3}{|c|}{ 62nd Session (2010) } \\
\hline 7. & $\begin{array}{l}\text { Effects of armed conflicts } \\
\text { on treaties (60th Session, } \\
2008 \text { ILC 1st reading) }\end{array}$ & $\begin{array}{l}\text { Austria, Burundi, China, Colombia, Cuba, } \\
\text { Ghana, the Islamic Republic of Iran, } \\
\text { Lebanon, Poland, Portugal, Slovakia, }\end{array}$ \\
\hline
\end{tabular}

76 Rep. of the G.A., Responsibility of International Organizations, U.N. Doc. A/CN.4/637 (2011).

77 Rep. of the G.A., Responsibility of International Organizations, U.N. Doc. A/CN.4/637/Add.1 (2011).

78 Rep. of the G.A., Reservations to Treaties, U.N. Doc. A/CN.4/639 (2011).

79 Rep. of the G.A., Effects of Armed Conflicts on Treaties, U.N. Doc. A/CN.4/622 (2010); Rep. of the G.A., Effects of Armed Conflicts on Treaties, U.N. Doc. A/CN.4/622/Add.1 (2010). 
[Vol. 13:1043

\begin{tabular}{|l|l|l|}
\hline & & $\begin{array}{l}\text { Switzerland and the United States of } \\
\text { America (2009-2010). }\end{array}$ \\
\hline 8. & $\begin{array}{l}\text { Expulsion of aliens (57th } \\
\text { Session, 2005, 59th } \\
\text { Session 2009 ILC) } 80\end{array}$ & $\begin{array}{l}\text { Germany, Mauritius, the Russian } \\
\text { Federation, and Switzerland (2008). } \\
\text { Andorra, Armenia, Bahrain, Belarus, } \\
\text { Bosnia and Herzegovina, Bulgaria, Canada, } \\
\text { China, Croatia, Cuba, the Czech Republic, } \\
\text { El Salvador, Finland, Germany, Italy, } \\
\text { Kuwait, Lithuania, Malaysia, Malta, } \\
\text { Mexico, New Zealand, Norway, Peru, } \\
\text { Portugal, Qatar, Republic of Korea, } \\
\text { Romania, Serbia, Singapore, Slovakia, } \\
\text { South Africa, Sweden, Switzerland, and the } \\
\text { United States (2010). }\end{array}$ \\
\hline
\end{tabular}

80 Rep. of the G.A., Expulsion of Aliens, U.N. Doc. A/CN.4/604 (2008); Rep. of the G.A., Expulsion of Aliens, U.N. Doc. A/CN.4/628 (2010); Rep. of the G.A., Expulsion of Aliens, U.N. Doc. A/CN.4/628/Add.1 (2010). 